\title{
The Capacity and the Quality of Heir Possible Interaction with Preliminary Questions
}

\begin{abstract}
The article contains an overview of the rules relating to the scope of application of the EU private international law regulations. It addresses the treatment of the relevant preliminary questions, with special reference to the Succession Regulation. The issues are discussed in three steps. The first is connected with the way of interpreting the notions and concepts, such as marriage, adoption, legal capacity etc., where such matters as personal status, legal capacity or family relationship may come to the foreground as a preliminary question. The second is dealing with the law applicable to the preliminary question. The author compares pros and cons of the "independent reference" (lex fori) and the "dependent reference" (lex causae) solutions, considering the latter as less effective, producing more negative consequences. The third step embraces questions relating to the jurisdiction with respect to preliminary question.
\end{abstract}

Keywords: private international law — EU Succession Regulation — capacity of heir legal capacity — preliminary questions — personal status — family relationships

\footnotetext{
a) Prof., University of Milan.
} 


\section{Overview of the EU private international law Regulations provisions on their respective scope of application and on the treatment of some relevant preliminary questions}

The European Succession Regulation (ESR) raises some issues and provides some solutions concerning the relationship between its scope of application (excluded vs included questions), the scope of the applicable law and preliminary questions that have been the object of extensive scholarly analysis in respect to the other EU regulations in the field of conflicts of laws. It is thus worth assessing such issues in order to establish if the solutions proposed in the ESR are the same as in the other EU regulations or if the peculiarities of succession matters require specific answers, as well as if any problems are still open.

The starting points are Recital 11 and Article 1 ESR. According to the former, "This Regulation should not apply to areas of civil law other than succession. For reasons of clarity, a number of questions which could be seen as having a link with matters of succession should be explicitly excluded from the scope of this Regulation". Article 1(2) provides the list of excluded matters, that includes "(a) the status of natural persons, as well as family relationships and relationships deemed by the law applicable to such relationships to have comparable effects; (b) the legal capacity of natural persons, without prejudice to point (c) of Article 23(2) and to Article 26; (c) questions relating to the disappearance, absence or presumed death of a natural person; ... (h) questions governed by the law of companies and other bodies, corporate or unincorporated"1.

Some of these matters are excluded also from the other EU private international law regulations, concerning jurisdiction and the applicable law ${ }^{2}$.

For example, Regulation No 593/2008 on the law applicable to contractual obligations (Rome I) excludes from its scope "(a) questions involving the status or legal capacity of natural persons, without prejudice to Article 13; (b) obligations arising out of family relationships and relationships deemed by the law applicable to such relationships to have comparable effects, including maintenance obligations; (c) obligations arising

${ }^{1}$ Issues arising in relation to company law will not be addressed in this paper.

${ }^{2}$ With the exception of Regulation No 4/2009, which does not provide a list of excluded matters, but it declares that it "shall apply to maintenance obligations arising from a family relationship, parentage, marriage or affinity" (Article 1(1)). 
out of matrimonial property regimes, property regimes of relationships deemed by the law applicable to such relationships to have comparable effects to marriage, and wills and succession".

Non-contractual obligations arising out of family relationships and relationships deemed by the law applicable to such relationships to have comparable effects, including maintenance obligations, and non-contractual obligations arising out of matrimonial property regimes, property regimes of relationships deemed by the law applicable to such relationships to have comparable effects to marriage, as well as wills and succession are excluded also from the scope of the Rome II Regulation on the law applicable to non-contractual obligations, ${ }^{3}$ that, however, does not mention questions involving the status or legal capacity of natural persons.

Both Regulations define the notion of "family relationships" as covering parentage, marriage, affinity and collateral relatives. Yet, neither are these notions defined, nor do their provisions offer any hint as to which law applies in order to assess whether such relationships exist in a given case. Reference is made to the lex fori only for purposes of defining "relationships having comparable effects to marriage and other family relationships" (Recitals 8 and 10, respectively).

Also the Rome III Regulation on the law applicable to divorce and legal separation ${ }^{4}$ excludes a list of issues that relate to status, capacity and family relationship, namely: (a) the legal capacity of natural persons; (b) the existence, validity or recognition of a marriage; (c) the annulment of a marriage; (d) the name of the spouses. It further specifies that they are excluded "even if they arise merely as a preliminary question within the context of divorce or legal separation proceedings" (Article 1(2)).

If one looks at Regulations No 2016/1103 and No 2016/1104 on the private international law issues arising out of matrimonial property and the economic effects of registered partnerships, respectively, they exclude a "number of questions which could be seen as having a link with matters of matrimonial property regime" and with the property consequences of registered partnerships (Recital 19), replicating the wording of Recital 11 ESR. Both Regulations exclude the legal capacity of spouses/ partners and the existence, validity or recognition of a marriage/registered partnership (Article 1(2)(a) and (b)). The definition of "marriage" is left to the national laws of the Member States (Recital 17 of Regulation No 2016/1103), while the "actual substance" of the notion of "registered partnership" "should remain defined in the national laws of the Member

${ }^{3}$ Regulation No 864/2007, Article 1(2)(a) and (b).

${ }^{4}$ Regulation No 1259/2010. 
States" (Recital 17 of Regulation No 2016/1104). In neither case do these provisions indicate whether reference to the domestic law of the Member States includes reference to its conflict of laws rules.

If one now turns to the Brussels-type Regulations, on jurisdiction and the recognition and enforcement of judgments, one sees that the Brussels Ia Regulation (No 1215/2012) excludes "the status or legal capacity of natural persons" (Article 1(2)(a)), while the Brussels IIa Regulation (No 2201/2003) does not apply to "(a) the establishment or contesting of a parent-child relationship; (b) decisions on adoption, measures preparatory to adoption, or the annulment or revocation of adoption; (c) the name and forenames of the child; (d) emancipation" (Article 1(3)). ${ }^{5}$

\section{Personal status and family relationships as preliminary questions}

This short overview shows that the solutions adopted by EU legislature largely coincide, that there is a sort of fil rouge (common thread) running among the various regulations, even if the wording is not always aligned, maybe due to the evolution of the rules over the years. The EU law-maker is perfectly aware that when applying these regulations, the excluded matters may come to the foreground as preliminary questions which have to be answered in order to decide the main questions included in their scope and brought in the courts of the Member States. Yet, no clear indication is provided on the law applicable to such questions.

The paradigm of the relationship between the issues included and excluded and preliminary questions in this respect is provided by the notions of "status", "capacity" and "family relations". Starting with personal status and family relationships, their existence occurs as a preliminary question in connection with succession matters in almost all cases, in particular in order to determine the beneficiaries, to whom the applicable law may reserve a share of the estate. The exclusion covers precisely the status of natural persons in respect to such incidental questions to succession matters. For example, if the law applicable to the succession designated by the ESR includes an adopted child or the partner of a registered partnership within the beneficiaries, the question of

\footnotetext{
${ }^{5}$ Cf. also Article 1(4)(a)-(d) of Regulation No 2019/1111 (Brussels IIa recast).
} 
whether an adoption or a registered partnership is valid falls outside the scope of Regulation. The same applies with regard to other issues, such as the validity of a marriage for the quality of spouse, the assessment of parentage for the quality of child or parent, whether legitimate or out-ofwedlock, and more generally for the existence of liens with the deceased and/or his/her (presumed) relatives ${ }^{6}$.

While interpreting the notions used in an EU private international law regulation, it is almost a reflex to refer to the other regulations, surmising that the system is coherent and consistent. This approach has been generally approved by the EU Court of Justice, mainly recalling the will to avoid gaps among the regulations that has been explicitly declared by the legislature. Yet, it should be kept in mind that in some instances the Court of Justice has established that some notions or provisions have to be interpreted independently from those used in other regulations, since the aim of assuring consistency cannot, in any event, lead to the provisions of a regulation being interpreted in a manner which is unconnected to the scheme and objectives pursued by it. ${ }^{7}$

Bearing this in mind, as already indicated, the Rome I and Rome II Regulations do not provide any hint, apart from a general definition of "family relationship". Yet, it could be inferred, and it has been inferred by the majority of commentators, that if such issues are excluded from their scope, they are left to the domestic law of the Member States, including their conflicts of laws rules. Moreover, these Regulations refer to the lex fori in order to interpret the notion of "relationships having comparable effects to marriage and other family relationships" in Article 1(2). ${ }^{8}$ This might imply that the so-called independent reference solution of the preliminary questions issue is adopted, albeit implicitly.

This solution is made explicit in the Rome III Regulation, which at Recital 10 clearly states that "Preliminary questions such as legal capacity and the validity of the marriage ... should be determined by the conflict-of-laws rules applicable in the participating Member State concerned". Article 1(2) then provides that "This Regulation shall not apply to the following matters, even if they arise merely as a preliminary question within the context of divorce or legal separation proceedings: ...”.

${ }^{6}$ M. Weller: Article 1. Scope, in The EU Succession Regulation, A Commentary. Eds. A.-L. Calvo Caravaca, A. Davì, H.-P- Mansel. Cambridge, 2016, pp. 73 ff, at 81 . The assessment of the death and the moment of the death are excluded from the ESR, as well as the establishment of disappearance, absence or presumed death of a natural person.

7 Cf. for example, CJEU, 16.1.2014, C-45/13 Kainz, ECLI:EU:C:2014:7.

${ }^{8}$ Cf. Art 1(2)(b) and (c) Rome I and Art 1(2)(a) and (b) Rome II and Recitals 8 and 10, respectively. 
More recently, the Regulations on matrimonial property and on the property consequences of registered partnership have gone in the same direction, where they state that they should not apply to other preliminary questions such as the existence, validity or recognition of a marriage/registered partnership, respectively, "which continue to be covered by the national law of the Member States, including their rules of private international law" (Recitals 21 of both Regulations).

The ESR follows the same route, insofar as it excludes "family relationships and relationships deemed by the law applicable to such relationships to have comparable effects" (Article 1(2)(a)). Moreover, the provisions on the Certificate of Succession explicitly state that it shall contain elements which have been established "under the law applicable to the succession or under any other law applicable to specific elements".

These provisions may be interpreted as meaning that the EU lawmaker favours the "independent reference" solution to the preliminary questions issue, which corresponds to the choice usually made by national legislatures in order to preserve the uniformity of solutions within a domestic legal system: the existence of the status or lien is always governed by the same law, designated by the domestic conflicts of laws rules, irrespective of whether it is assessed as main or as preliminary question. ${ }^{10}$ Indeed, the "dependent reference", according to which the preliminary question should be governed by the same law applicable to the main question (lex causae), including its conflicts-of-laws rules, is seldom used in the legal systems of the Member States. ${ }^{11}$

The "independent reference" in applying the EU private international law instruments is particularly effective in terms of achieving the uniformity of solutions within the EU when the preliminary question is governed by an EU regulation, as it happens, for example, with the dissolution of marriage under Rome III, that is, when the Member States are bound by unitary rules on the preliminary questions that point to the same applicable law $^{12}$. When no common rules exist, this advan-

${ }^{9}$ Art 69(2): "The Certificate shall be presumed to accurately demonstrate elements which have been established under the law applicable to the succession or under any other law applicable to specific elements. The person mentioned in the Certificate as the heir, legatee, executor of the will or administrator of the estate shall be presumed to have the status mentioned in the Certificate". Art 67(1): "The issuing authority shall issue the Certificate without delay in accordance with the procedure laid down in this Chapter when the elements to be certified have been established under the law applicable to the succession or under any other law applicable to specific elements".

${ }^{10}$ A. Bonomi: Successions internationales: conflits de lois et de juridictions. "Recueil des cours"2010, vol. 350, p. 323.

11 Ibidem, p. 324.

${ }^{12}$ Cf. also M. Weller: Article 1..., p. 83. 
tage would be lost at the level of EU law, but uniformity would still be achieved at national level.

Recourse to the "dependent reference" should not be retained, then. Within the system of the ESR, it has even more negative consequences. Not only would it lead to lack of internal uniformity, but it is subject to a further major critical argument: it would allow the testator to choose the law applicable to the preliminary question when he/she chooses the law applicable to the succession. ${ }^{13} \mathrm{~A}$ third position could be that since the regulations exclude these questions from their scope, each Member State is free to choose the solution it prefers, "independent" or "dependent" reference. This approach, however, would lead to divergences when the connecting factors used in the domestic legal systems differ, and in particular it might create problems for the recognition of Certificates of Succession $^{14}$.

If one thus follows the "independent reference" solution, which is supported by the majority of scholars, at least as far as national legal systems are concerned, a further question has to be answered. When a court is seized with the main action on succession, is it empowered to decide a preliminary question on the existence of a status or a family relationship with effects limited to the specific main proceedings, or should it- if such court is not the court vested with jurisdiction to hear that question with erga omnes effect - stay the main proceedings? ${ }^{15}$ In other words, should a GAT-like approach apply? ${ }^{16}$

${ }_{13}$ According to A. Bonomi, however, this outcome is not so relevant since under the ESR the testator can only choose one law, his/her national law (A. Bonomi: Article 22. Choix de la loi. In: Le droit européen des successions, Commentaire du Règlement $n^{\circ}$ 650/2012 du 4 juillet 2012. Dir. A. Bonomi, P. Wautelet. Bruxelles, 2013, p. $\left.301 \mathrm{ff}\right)$. The solution could be to adopt the "independent reference" only if the testator has chosen the applicable law, but this would lead to divergent solutions in applying the ESR to a preliminary question depending upon whether the testator has chosen the applicable law or not. A second general criticism raised against the "dependent reference" - namely, that it would run counter to the prohibition of renvoi provided in the EU private international law regulations - cannot be raised in the case of ESR since this Regulation allows renvoi in certain cases and at certain conditions.

${ }^{14}$ A. Bonomi: Successions internationales..., p. 325.

${ }^{15}$ G. Biagioni: L'ambito di applicazione del regolamento sulle successioni, in $\mathrm{Il}$ diritto internazionale privato delle successioni mortis causa. A cura di P. Franzina, A. Leandro. Milan 2013, pp. 47-48.

16 CJEU, 13.7.2006, C-4/03 GAT, ECLI:EU:C:2006:457: "Article 16(4) of the 1968 Brussels Convention is to be interpreted as meaning that the rule of exclusive jurisdiction laid down therein concerns all proceedings relating to the registration or validity of a patent, irrespective of whether the issue is raised by way of an action or a plea in objection". 
In order to answer this question, one should consider that, on the one hand, the Court of Justice has been very explicit and rigid when interpreting the Brussels IIa Regulation, in establishing a clear boundary between this Regulation and other regulations, for instance, the Maintenance Regulation. In Matoušková ${ }^{17}$, the CJEU has stated that splitting the decision-making process concerning matters relating to a succession between two different Member States, one in which the succession proceedings have been opened and the other which is the habitual residence of the child for designating a representative of the child who would approve an agreement for the sharing-out of an estate (concluded by a guardian ad litem on behalf of minor children), laid down in Article 8(1) of Regulation No 2201/2003, is mandatory under the Regulations and does not compromise the best interests of the child. The jurisdiction of each court is well defined by the EU rules and must be respected. In our perspective, one might surmise that if the preliminary question were included within the scope of another EU private international law regulation, it should be brought in the court designated by such regulation. Yet, where no EU uniform provisions exist for determining the court competent to assess a preliminary question, such as the existence of a status or the validity of a marriage, the answer should be sought elsewhere.

On the other hand, however, Articles 67(1) and 69(2) ESR concerning the Certificate of Succession mention elements "which have been established under any other law applicable to specific elements". Recital 71 clarifies that "The Certificate ... should have an evidentiary effect and should be presumed to demonstrate accurately elements which have been established under the law applicable to the succession or under any other law applicable to specific elements, such as the substantive validity of dispositions of property upon death. The evidentiary effect of the Certificate should not extend to elements which are not governed by this Regulation, such as questions of affiliation ...". These provisions seem to imply that the assessment of such elements is carried out by the same authority that drafts the Certificate, and that the jurisdiction on the merits concerning the succession includes the power to assess preliminary questions as well, such as the establishment of a status or a family relationship, irrespective of whether that authority has jurisdiction to decide them with erga omnes effect, based upon national (or EU, if any) jurisdiction rules. ${ }^{18}$

${ }^{17}$ CJEU, 6.10.2015, C-404/14, ECLI:EU:C:2015:653.

${ }_{18}$ It is worth mentioning that the 2019 Hague Judgments Convention has a provision on preliminary questions, which implies that a court is empowered to decide such questions if they are raised in a judicial proceeding. According to Article 8(2), recogni- 
This solution is to be preferred also because the authority that is competent to decide on the succession and to issue the Certificate under the ESR may be a notary public and not a court. Moreover, and even more convincingly, according to Article 59(4) ESR concerning authentic instruments, "If the outcome of proceedings in a court of a Member State depends on the determination of an incidental question relating to the legal acts or legal relationships recorded in an authentic instrument in matters of succession, that court shall have jurisdiction over that question". ${ }^{19}$

Finally, as already mentioned, another argument in favour of the competence of the same authority vested with jurisdiction on the succession to decide preliminary questions can be drawn from Recital 10 of the Rome III Regulation, that seems to allow the court seized for the succession matter to decide on the preliminary question as well when it states that "Preliminary questions such as legal capacity and the validity of the marriage ... should be determined by the conflict-of-laws rules applicable in the participating Member State concerned", that is, in the Member State of the court seized of the main question. It is important to notice that the EU legislature mentions together legal capacity, which may undisputedly be assessed by the same court competent for the succession, and the validity of the marriage.

The fact that, according to the Court of Justice, in case the issue concerning the validity of marriage is raised as a main question through an action for the annulment of a marriage after the death of one of the spouses for purposes of a succession proceedings, the competent court is determined by the Brussels Ia Regulation, ${ }^{20}$ does not affect the approach that is suggested above. In fact, in that case the validity of marriage was the main question brought in the national court, for which the Brussels Ia Regulation provides a unitary jurisdiction criterion to be respected. Had such issue been raised as a preliminary question within the main proceedings on the succession, it could have been decided by the same court competent for these proceedings.

tion or enforcement of a judgment may be refused if, and to the extent that, the judgment was based on a ruling on a matter to which the Convention does not apply.

${ }_{19}$ Recital 64: "If a question relating to the legal acts or legal relationships recorded in an authentic instrument is raised as an incidental question in proceedings before a court of a Member State, that court should have jurisdiction over that question".

${ }^{20}$ CJEU, 13.10.2016, C-294/15 Mikołajczyk, ECLI:EU:C:2016:772. 


\section{Legal capacity as preliminary question}

Having examined the possible solutions for the assessment of preliminary questions concerning status and family relationships, one may proceed to addressing the issue of legal capacity of natural persons as preliminary question.

Legal capacity is excluded from the Rome I Regulation (Article 1(2 (a), without prejudice to Article 13 on incapacity) ${ }^{21}$, from the Rome III Regulation (Article 1(2)(a)), from Regulation No 2016/1103 (Article 1(2 (a)) ${ }^{22}$ and from Regulation No 2016/1104 (Article 1(2)(a)). ${ }^{23}$ The capacity to choose the applicable law/to enter into an agreement on choice of law is determined by the law which would govern the agreement under the regulation in question if the agreement or term were valid under Articles 3(5) and 10 of the Rome I Regulation, Article 6 of the Rome III Regulation, and the respective Articles 24 of Regulations No 2016/1103 and No $2016 / 1104^{24}$.

As indicated above, also the ESR excludes the legal capacity of natural persons from its scope of application, without prejudice to Article 23(2) (c) and Article 26. The former includes the capacity to inherit within the scope of the applicable law (and thus within the scope of the Regulation); the latter states that the capacity of the person making the disposition of property upon death to make such a disposition pertains to substantive validity and thus it (falls within the Regulation and) is governed by the law "which, under this Regulation, would have been applicable to the

21 "In a contract concluded between persons who are in the same country, a natural person who would have capacity under the law of that country may invoke his incapacity resulting from the law of another country, only if the other party to the contract was aware of that incapacity at the time of the conclusion of the contract or was not aware thereof as a result of negligence".

${ }^{22}$ Recital 20: "Accordingly, this Regulation should not apply to questions of general legal capacity of the spouses; however, this exclusion should not cover the specific powers and rights of either or both spouses with regard to property, either as between themselves or as regards third parties, as these powers and rights should fall under the scope of this Regulation".

${ }^{23}$ Recital 20: "Accordingly, this Regulation should not apply to questions of general legal capacity of the partners; however, this exclusion should not cover the specific powers and rights of either or both partners with regard to property, either as between themselves or as regards third parties, as these powers and rights should fall under the scope of this Regulation".

${ }^{24}$ The Rome II Regulation does not mention this issue, albeit in certain cases it allows the parties to choose the law applicable to the non-contractual obligation at stake (Article 14). 
succession of the person who made the disposition if he had died on the day on which the disposition was made".

Thus, the capacity to inherit and the capacity to dispose of one's assets are subject to the ESR, that determines the applicable law to them, namely, the law applicable to the succession at the moment of the death and the law that would have applied to the succession had the testator died when the disposition was made, respectively. The rationale is that they are "special" capacities relevant only within the context of the main matter ${ }^{25}$.

As far as the capacity to inherit is concerned, it includes the capacity of the unborn child or a legal entity, the conditions that a minor must satisfy in order to inherit, incapacities or prohibitions to inherit in certain circumstances, the capacity to inherit by will, that, consequently, are governed by the same law that applies to the succession ${ }^{26}$.

As regards the capacity to make a disposition of property upon death, such as the capacity to make a disposition for a person under age or a legally incapacitated adult, it must be assessed according to the law of the State of the habitual residence of the person concerned on that day or, if he had made a choice of law under this Regulation, the law of the State of his nationality on that day (Recital 51).

If subsequently the testator changes the habitual residence or the nationality, the conditions laid down by that law for that special capacity continue to apply ${ }^{27}$. It is the same solution followed in the Rome 1 Regulation and the other regulations mentioned above and is particularly welcome both for granting coherence within the EU private international law instruments and to avoid that domestic conflicts of laws rules apply. Moreover, it is also in line with the 1989 Hague Convention on the law applicable to succession to the estates of deceased persons (Article 5(2)) ${ }^{28}$.

${ }_{25}$ The same solution is adopted in the Rome II Regulation, which states at Article 15 (Scope of the applicable law) that "The law applicable to non-contractual obligations under this Regulation shall govern in particular: (a) the basis and extent of liability, including the determination of persons who may be held liable for acts performed by them".

${ }^{26}$ For example, for the notary public who assists in drafting the will, the doctor who assists the deceased, the tutor of the deceased. Cf. E. Castellanos Ruiz: "Article 23. The Scope of the Applicable Law," in The EU Succession Regulation, A Commentary. Eds. A.-L. Calvo Caravaca, A. Davì, H.-P- Mansel. Cambridge 2016, at 356. According to A. Bonomi, however, the latter incapacities pertain to the validity of the will and are thus governed by the law designated by Articles 24 and 25 (A. Bonomi: "Article 23. Portée de la loi applicable," in Le droit européen des successions, Commentaire du Règlement $n^{\circ}$ 650/2012 du 4 juillet 2012. Dir. A. Bonomi, P. Wautelet. Bruxelles 2013, at 352 and 421$)$.

${ }^{27}$ A. Bonomi: "Article 26. Validité au fond des dispositions à cause de mort," in Le droit européen des successions, Commentaire du Règlement $n^{\circ}$ 650/2012 du 4 juillet 2012. Dir. A. Bonomi, P. Wautelet. Bruxelles 2013, at 418.

${ }^{28}$ A. Bonomi: Successions internationals..., p. 249. 
On the contrary, the capacity to accept the inheritance or renounce it falls within the general capacity and is thus excluded from the ESR.$^{29}$ For example, if the law applicable to the succession requires a certain age, it has to be ascertained according to the law applicable to the general legal capacity of the heir. The same applies to personality rights post mortem and issues related to the deceased as a person ${ }^{30}$.

These issues may fall under the domestic law of the court seized or under an international convention or an EU Regulation. For example, the representation and the protection of minors or incapacitated adults may be subject to the Hague Conventions of 1996 and 2000, respectively, and/or to the Brussels IIa Regulation. In particular, the Regulation applies to the attribution, exercise, delegation, restriction or termination of parental responsibility, which may deal with measures for the protection of the child relating to the administration, conservation or disposal of the child's property, as per Article 1(1)(b) and (2)(e) ${ }^{31}$.

The EU Court of Justice has been very clear in this respect in two judgments. Albeit they were rendered on cases falling outside the temporal scope of the ESR and they concerned issues of jurisdiction, drawing the line between the ESR and the Brussels IIa Regulation, they mention the Succession Regulation and thus they should be taken into consideration also for purposes of interpreting its provisions in their entirety, since the scope application of the provisions on jurisdiction and on the applicable law is the same.

In Matoušková, that concerned the approval of an agreement for the sharing-out of an estate concluded by a guardian ad litem on behalf of minor children, the Court of Justice has stated that "such approval is a measure taken having regard to the legal capacity of the minor", that "relates directly to the legal capacity of a natural person and, by its nature, constitutes an action intended to ensure that the requirements of protection and assistance of minor children are met. ... [L]egal capacity and the associated representation issues must be assessed in accordance with their own criteria and are not to be regarded as preliminary issues dependent on the legal acts in question. Therefore, it must be held

29 A. Bonomi: Article 1. Champ d'application, in Le droit européen des successions, Commentaire du Règlement $n^{\circ}$ 650/2012 du 4 juillet 2012. Dir. A. Bonomi, P. Wautelet. Bruxelles 2013, at 80; D. Da mascelli: L'acquisto dell'eredità o del legato da parte dell'incapace: coordinamento tra "statuto successorio" e "statuto di protezione", "Rivista di diritto internazionale privato e processuale", 2019, pp. $54 \mathrm{f}$.

${ }^{30}$ Cf. M. Weller: Article 1..., p. 85.

${ }^{31}$ Recital 9: "As regards the property of the child, this Regulation should apply only to measures for the protection of the child, i.e. (i) the designation and functions of a person or body having charge of the child's property, representing or assisting the child, and (ii) the administration, conservation or disposal of the child's property". 
that the appointment of a guardian for the minor children and the review of the exercise of her activity are so closely connected that it would not be appropriate to apply different jurisdictional rules, which would vary according to the subject-matter of the relevant legal act. Therefore, the fact that the approval at issue in the main proceedings has been requested in succession proceedings cannot be regarded as decisive as to whether that measure should be classified as falling within the law on succession. The need to obtain approval from the court dealing with guardianship matters is a direct consequence of the status and capacity of the minor children and constitutes a protective measure for the child relating to the administration, conservation or disposal of the child's property in the exercise of parental responsibility within the meaning of Article 1(1)(b) and 2(e) of Regulation No 2201/2003. Such an interpretation is supported by the report of Mr Lagarde on the Hague Convention 1996 on Jurisdiction, Applicable Law, Recognition, Enforcement and Co-operation in Respect of Parental Responsibility and Measures for the Protection of Children, the scope of which corresponds with regard to parental responsibility to that of Regulation No 2201/2003. While explaining that successions must, in principle, be excluded from that convention, the report states that, if the legislation governing the rights to succession provides for the intervention of the legal representative of the child heir, that representative must be designated in accordance with the rules of the convention, since such a situation falls within the area of parental responsibility. That interpretation is also confirmed by Regulation No 650/2012, not applicable ratione temporis in the case in the main proceedings, which, in accordance with recital 9 in the preamble thereto, was adopted in order to cover all civil law aspects of succession to the estates of a deceased person. Article 1(2)(b) thereof excludes from its scope the legal capacity of natural persons. That regulation governs only the aspects relating specifically to the capacity to inherit, under Article 23(2)(c) thereof, and the capacity of the person making the disposition of property upon death to make such a disposition in accordance with Article 26(1)(a) thereof." 32

This judgment was recently confirmed in Saponaro, ${ }^{33}$ that concerned the authorisation to renounce an inheritance. Recalling Matoušková, the Court of Justice stated that "it is necessary to regard an application lodged by parents in the name of their minor child for authorisation to renounce an inheritance as being concerned with the status and capacity

${ }^{32}$ Fn. 17, paras. $28-33$. Cf. the text in fn. 20 for the discussion on the possibility to raise an issue concerning status, family relationships or capacity as a preliminary question with effects inter partes.

${ }^{33}$ CJEU, 9.4.2018, C-565/16 Saponaro, ECLI:EU:C:2018:265, paras. 18-19. 
of the person". Thus, "such an application does not fall within the law on succession but within that of parental responsibility and [...] therefore, the question referred must be examined having regard to Regulation No 2201/2003."

\section{References}

Biagioni G.: L'ambito di applicazione del regolamento sulle successioni, in Il diritto internazionale privato delle successioni mortis causa. A cura di P. Franzina, A. Leandro. Milan 2013.

Bonomi A.: Successions internationales: conflits de lois et de juridictions. "Recueil des cours" 2010, vol. 350.

Bonomi A.: Article 22. Choix de la loi. In: Le droit européen des successions, Commentaire du Règlement $n^{\circ}$ 650/2012 du 4 juillet 2012. Dir. A. Bonomi, P. Wautelet. Bruxelles 2013.

Castellanos Ruiz E.: "Article 23. The Scope of the Applicable Law," in The EU Succession Regulation, A Commentary. Eds. A.-L. Calvo Caravaca, A. Davì, H.-P- Mansel. Cambridge 2016.

Damascelli D.: L'acquisto dell'eredità o del legato da parte dell'incapace: coordinamento tra "statuto successorio" e "statuto di protezione». "Rivista di diritto internazionale privato e processuale", 2019.

Weller M.: Article 1. Scope, in: The EU Succession Regulation, A Commentary. Eds. A.-L. Calvo Caravaca, A. Davì, H.-P- Mansel. Cambridge 2016. 